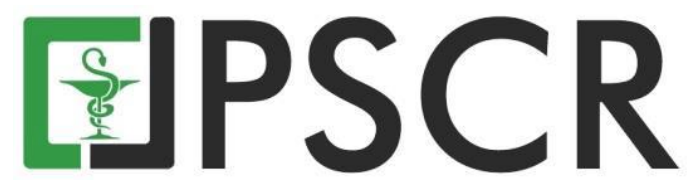

\title{
Evaluasi Persepsi Interprofessional Education dan Efektivitasnya Pada Tingkat Pengetahuan Tenaga Kesehatan Tentang KB Oral dan Suntik di Kota Bandung
}

\author{
Ikhwan Y. Kusuma ${ }^{1^{*}}$ dan Kusnandar Anggadiredja ${ }^{2}$ \\ ${ }^{1}$ Program Studi S1 Farmasi, Fakultas Kesehatan, Universitas Harapan Bangsa, Jl. Raden Patah No. 100, Ledug, \\ Banyumas, Indonesia \\ ${ }^{2}$ Sekolah Farmasi, Institut Teknologi Bandung, Jl. Ganesa 10 Bandung 40132, Indonesia \\ *email korespondensi: ikhwanyudakusuma@uhb.ac.id
}

\begin{abstract}
Abstrak: Pembangunan di bidang kesehatan dipengaruhi pertumbuhan penduduk. Provinsi Jawa Barat memiliki populasi penduduk terbanyak di Indonesia. Upaya pemerintah menekan laju pertumbuhan penduduk ialah melalui optimalisasi penggunaan kontrasepsi pada program Keluarga Berencana (KB). Metode kontrasepsi terbanyak di Jawa Barat, khususnya Kota Bandung dengan $\mathrm{KB}$ oral dan $\mathrm{KB}$ suntik. Optimalisasi kinerja tenaga kesehatan diperlukan agar mampu memberikan informasi yang relevan kepada akseptor KB untuk meningkatkan kepatuhan. Interprofessional Education (IPE) merupakan satu upaya mewujudkan program pelayanan KB yang berkualitas, melalui peningkatan kompetensi pelayanan KB. Kolaborasi interprofesi diharapkan mampu memberikan peningkatan kompetensi, sikap, dan keterampilan yang dibutuhkan untuk bekerjasama secara efektif. Penelitian ini bertujuan untuk mengidentifikasi tingkat pengetahuan tenaga kesehatan (apoteker, asisten apoteker, dokter, perawat, bidan, dan Sarjana Kesehatan Masyarakat) di Puskesmas yang bertanggungjawab dan berkaitan langsung dalam pelayanan $\mathrm{KB}$ dan Petugas Lapangan KB (PLKB) penanggungjawab di tingkat kecamatan terkait obat kontrasepsi oral dan suntik serta mengevaluasi persepsi tenaga kesehatan terhadap IPE di kota Bandung. Metode penelitian ini adalah eksperimental tipe one group pre-post test design. Hasil analisis menunjukkan tingkat pengetahuan tenaga kesehatan, sebanyak 5 orang mengalami penurunan, 152 orang mengalami peningkatan dan 4 orang tidak mengalami perubahan. Sedangkan hasil analisis mengenai persepsi tenaga kesehatan terhadap IPE, sebanyak 22 orang mengalami penurunan, 114 orang mengalami peningkatan, dan 25 orang tidak mengalami perubahan. Kesimpulan penelitian ini ialah IPE Focus Group Discussion secara signifikan mampu meningkatkan pengetahuan tenaga kesehatan tentang $\mathrm{KB}$ oral dan suntik serta secara signifikan meningkatkan persepsi untuk berkolaborasi antar profesi.
\end{abstract}

Kata kunci: Keluarga berencana; Interprofessional education; Pengetahuan; Persepsi

\section{Abstract. Evaluation of Antibiotic Use in Internal Medicine Ward at Bangil District}

Hospital. Development in the health sector is affected by population growth. West Java Province has the largest population in Indonesia. The government's educe the rate of population growth with Family Planning (FP) program. Most contraceptive methods in Bandung is oral and injection contraceptions. Optimization of the performance of health personnel is needed to provide relevant information to improve compliance acceptors of family planning acceptors, especially for oral and injectable. Interprofessional Education is an effort to manifest quality PF program, through the improvement of competence of PF service. Interprofessional collaboration is expected to be able to provide increased competence, attitudes, and skills necessary can work effectively together. This study was aimed to identify 
the level knowledge of health personnel related to oral and injectable contraceptive drugs and evaluate the perceptions of health personnel on IPE in the city of Bandung. Research method of this experimental is type one group pre-post test design. The data was analyzed using a Willcoxon rank test from questionnaires on knowledge of health personnel (pharmacists, pharmacist assistants, doctors, nurses, midwives, and Bachelor of Public Health) in the Puskesmas and directly related to KB services and KB Field Officers (PLKB) in charge at the district level with oral and injection contraceptives and questionnaires on the perceptions of health personnel on IPE before and after FGD (Focus Group Discussion). This study showed that the level of knowledge decreased in 5 health personnel, increased in 152 personnel and no change observed in 4 personnel. Meanwhile, the result of analysis on perception of health personnel on IPE demonstrated decrease in 22 personnel, increase in 114 personnel, and no changes in 25 personnel. The results of the present study showed that IPE Focus Group Discussion significantly increased the knowledge of health personnel on injection contraceptives and significantly increased perceptions on the need to collaborate between health professionals.

Keywords: Family planning; Interprofessional education; Knowledge; Perception

\section{Pendahuluan}

Dinamika kependudukan mempengaruhi mempengaruhi tingkat kesehatan suatu negara. Badan Pusat Statistik menyatakan terjadi peningkatan jumlah penduduk di Indonesia, laju pertumbuhan penduduk Indonesia sebesar 1,19\% per tahun, jumlah penduduk pada tahun 2015 ialah 256.461 .700 orang dan diperkirakan meningkat menjadi 268.074.600 orang pada tahun 2019. Wanita usia subur diperkirakan akan meningkat jumlahnya sebanyak 68,1 juta menjadi 71,2 juta dari tahun 2015 hingga 2019 dengan perkiraan bahwa setiap tahun akan ada 5 juta ibu hamil. Jumlah tersebut merupakan estimasi jumlah bayi lahir dan jumlah persalinan, yang menggambarkan beban pelayanan ANC (Antenatal Care), persalinan, dan angka neonatus/ bayi. Manurut data BPS Provinsi Jawa Barat memiliki populasi jumlah penduduk terbanyak yaitu sebesar 46.709.569 jiwa (BPS Indonesia, 2013 dan Kemenkes, 2015).

Upaya pemerintah untuk menekan laju pertumbuhan penduduk ialah melalui program Keluarga Berencana (KB) sesuai Peraturan Pemerintah Republik Indonesia Nomor 87 Tahun 2014 tentang Perkembangan Kependudukan dan Pembangunan Keluarga, Keluarga Berencana, dan Sistem Informasi Keluarga. Program keluarga berencana (KB) merupakan upaya mengelola kelahiran anak, usia dan jarak ideal melahirkan, pengelolaan kehamilan, melalui promosi, perlindungan, dan bantuan sesuai dengan hak reproduksi dalam rangka menciptakan keluarga yang berkualitas (Kemenkes, 2014a). Keluarga Berencana (KB) juga dapat mencegah kehamilan berisiko tinggi, yaitu kehamilan dengan kondisi terlalu muda melahirkan (di bawah usia 18 tahun), terlalu sering melahirkan (lebih dari 4 kali), terlalu dekat jarak melahirkan (kurang dari 2 tahun), dan terlalu tua melahirkan (di atas usia 35 tahun) (Senanayake, 2008). 
Data statistik BKKBN hingga Maret 2017 menunjukkan jumlah pengguna KB aktif di Indonesia saat ini ialah sebanyak 23.909.367 akseptor. Berdasarkan data tersebut sebanyak 5.654.907 akseptor berada di Provinsi Jawa Barat dengan 226.337 akseptor KB aktif berasal dari Kota Bandung (BKKBN, 2017). Pola penggunaan KB pada sebagian besar masyarakat lebih condong pada penggunaan KB suntik dan pil. Kedua jenis alat kontrasepsi ini dianggap mudah diperoleh dan digunakan oleh pasangan usia subur (Kemenkes, 2014a). Jumlah pengguna KB pil di Kota Bandung sebanyak 34.822 akseptor (15,39\%), sedangkan pengguna KB suntik sebanyak 98.055 akseptor (43,32\%) (BKKBN, 2017).

Keluarga Berencana melibatkan 3 dinamika dan elemen interaktif yaitu metode pengaturan di masa subur, pelayanan kesehatan oleh tenaga kesehatan, serta persepsi dan karakteristik akseptor (Senanayake, 2008). Sejalan dengan tujuan pelayanan KB oleh tenaga kesehatan, maka dukungan manajemen dalam pelayanan KB menjadi sangat penting yang di mulai dari Perencanaan, Pelaksanaan, serta Pemantauan dan Evaluasi (Kemenkes, 2014b)

Pelayanan $\mathrm{KB}$ oleh tenaga kesehatan dalam bentuk sistem informasi dan pendidikan yang komunikatif merupakan faktor yang paling penting dalam optimalisasi kepatuhan akseptor KB serta menjadi pedoman penentuan pilihan kontrasepsi bagi akseptor. Tingkat putus pakai kontrasepsi tahun 2016 yang mencapai 25,7 \% menjadi sasaran strategis BKKBN 2015 - 2019 untuk melakukan peningkatan pelayanan KB dengan penggunaan MKJP (Model Kontrasepsi Jangka Panjang) dalam upaya mengurangi risiko drop-out serta pemakaian KB non-MKJP (BKKBN, 2017). Oleh karena itu, optimalisasi kinerja dan kompetensi petugas pelaksana penyuluhan yaitu tenaga kesehatan perlu ditingkatkan sehingga mampu memberikan informasi yang relevan kepada akseptor KB untuk meningkatkan pengetahuan dan kepatuhan akseptor terutama pada penggunaan KB hormonal secara oral dan suntik (Senanayake, 2008). Sampai saat ini, data mengenai kinerja dan kompetensi petugas pelaksana penyuluhan belum banyak dilakukan.

Pemberian kontrasepsi oral dan suntik memerlukan tingkat kepatuhan yang tinggi, hal ini dikarenakan tingginya angka kegagalan program $\mathrm{KB}$ akibat penurunan efek dan peningkatan potensi efek samping akibat ketidakpatuhan akseptor (Allen dan Cwiak, 2014). Interprofessional Education (IPE) merupakan pendekatan solusi untuk meningkatkan kompetensi petugas pelaksana penyuluhan (tenaga kesehatan) melalui proses pendidikan yang berbeda berkolaborasi dengan dua atau lebih disiplin ilmu dalam proses belajar-mengajar yang tujuan untuk membina interaksi interprofessional guna meningkatkan praktek disiplin masing-masing profesi (Barr dan Low, 2013). Levi, dkk. 2013 dan Cappiello, dkk. 2016 menjelaskan kolaborasi antarprofesi kesehatan dalam bentuk IPE mampu meningkatkan 
kualitas pelayanan kesehatan melalui peningkatan kompetensi di seluruh disiplin ilmu dan profesi dalam perawatan kesehatan seksual dan reproduksi.

IPE merupakan satu upaya mewujudkan program pelayanan KB yang berkualitas, melalui peningkatan kompetensi pelayanan KB yaitu tenaga kesehatan dimana kolaborasi interprofesi ini mampu mengidentifikasi tingkat pengetahuan tenaga kesehatan terkait obat kontrasepsi, menganalisis faktor-faktor yang berhubungan dengan kapasitas tenaga kesehatan dalam kegiatan penyuluhan $\mathrm{KB}$, serta kolaborasi interprofesi mampu menentukan informasi penting yang harus akseptor ketahui terkait penggunaan $\mathrm{KB}$ oral dan suntik. Oleh karena itu perlu dilakukan penelitian untuk mengevaluasi persepsi interprofessional education dan efektivitasnya pada tingkat pengetahuan tenaga kesehatan tentang KB oral dan suntik di Kota Bandung.

\section{Metode}

Penelitian ini dilakukan melalui kajian pengetahuan dan persepsi tenaga kesehatan terhadap IPE, dimana kajian dilakukan sebelum dan setelah dilakukan FGD (Focus Group Discussion) antar profesi kesehatan menggunakan kuesioner formal. Jenis penelitian ini adalah penelitian eksperimen dengan rancangan one group pre-post test design. Penelitian ini dimulai dengan melakukan uji validitas dan reabilitas kuesioner kepada tenaga kesehatan untuk mengetahui validitas dan reliabilitas kuesioner yang di adaptasi dari PINCOM-Q (Perception of Interprofessional Colaboration Model Questionaire) (Health dkk., 2012), IELPS (Interdiciplinary Education Perception Scale) (McFadyen dkk., 2007), RIPLS (Readiness for Inter-professional Learning Scale Questionnaire) (Parsell dan Bligh, 1999), dan penelitian Ulung (2014) tentang Persepsi Mahasiswa Fakultas Kedokteran dan Ilmu Kesehatan UIN Syarif Hidayatullah Jakarta terhadap Interprofessional Education, dan berdasarkan literatur yang terkait dengan pengetahuan tentang KB oral dan suntik.

Setelah kuisioner teruji valid dan reliabel, dilakukan seleksi terhadap calon responden serta pencatatan data tenaga kesehatan di masing-masing Puskesmas berdasarkan dengan kriteria yang telah ditentukan. Informed consent akan diberikan kepada calon responden yang memenuhi kriteria, kemudian responden terpilih akan diberikan penjelasan mengenai cara pengisian kuesioner. Kuesioner Pre Test diberikan untuk mengetahui persepsi tenaga kesehatan terhadap IPE dan mengetahui tingkat pengetahuan tenaga kesehatan tentang KB oral dan suntik selama kurang lebih 20 menit kepada responden yang terpilih. Penelitian dilanjutkan dengan pemberian penjelasan oleh peneliti kepada tenaga kesehatan di Puskesmas terkait konsep IPE dan dilakukan Focus Group Discussion dengan peserta tenaga kesehatan di Puskesmas yang terdiri dari minimal 2 profesi berbeda. Responden diberikan kuesioner Post 
Test untuk mengetahui persepsi tenaga kesehatan terhadap IPE serta pengetahuan tenaga kesehatan tentang KB oral dan suntik setelah FGD. Informasi yang sudah dikumpulkan melalui kuesioner akan diseleksi lagi oleh peneliti dengan hanya mengambil kuesioner yang diisi lengkap. Selanjutnya peneliti akan mengolah dan menganalisa kuesioner yang telah diisi.

\subsection{Subjek Penelitian}

Penelitian ini menggunakan teknik sampling area (cluster) dan subyek penelitian ini ditetapkan oleh Badan Pemberdayaan Perempuan dan Keluarga Berencana (BPPKB) Kota Bandung dan Dinas Kesehatan Kota Bandung yaitu tenaga kesehatan yang bertanggung jawab di UPT Puskesmas Caringin, UPT Puskesmas Talaga Bodas, UPT Puskesmas Padasuka, UPT Puskesmas Margahayu Raya, UPT Puskesmas Ujung Berung, dan UPT Puskesmas Garuda. Dalam penelitian ini subjek penelitian ditentukan oleh kriteria inklusi dan kriteria eksklusi. Kriteria inklusi dalam penelitian ini adalah tenaga kesehatan (apoteker, asisten apoteker, dokter, perawat, bidan, dan Sarjana Kesehatan Masyarakat) di Puskesmas yang bertanggungjawab dan berkaitan langsung dalam pelayanan KB dan Petugas Lapangan KB (PLKB) penanggungjawab di tingkat kecamatan. Subjek yang memenuhi kriteria inklusi akan ditanyakan kesediaan untuk ikut serta dalam penelitian ini melalui Informed Consent yang terlampir pada lampiran. Kriteria eksklusi dalam penelitian ini adalah tenaga kesehatan yang tidak terkait langsung dengan pelayanan KB dan PLKB yang belum pernah mengikuti pelatihan terkait pelayanan KB.

\subsection{Data dan Sumber Data}

Bahan dan sumber data yang digunakan dalam penelitian ini yaitu menggunakan data primer. Pada penelitian ini sumber data diperoleh dari responden dengan daftar pertanyaan yang terdapat pada kuesioner mengenai pengetahuan tenaga kesehatan tentang KB oral dan suntik serta kuesioner mengenai persepsi tenaga kesehatan terhadap IPE sebelum dan setelah dilakukan FGD (Focus Group Discussion) antar profesi tenaga kesehatan.

\subsection{Tempat dan Waktu Penelitian}

Tempat yang digunakan untuk penelitian yaitu UPT Puskesmas Caringin, UPT Puskesmas Talaga Bodas, UPT Puskesmas Padasuka, UPT Puskesmas Margahayu Raya, UPT Puskesmas Ujung Berung, dan UPT Puskesmas Garuda. Validasi kuesioner dilakukan pada bulan Maret hingga April 2017, kemudian dilakukan penelitian dengan kuesioner pada bulan Mei hingga November 2017.

\subsection{Analisis Data}

Kuesioner mengenai pengetahuan tentang $\mathrm{KB}$ oral dan suntik dan mengenai persepsi IPE diujicobakan dahulu untuk dinilai validitas dan reliabilitasnya. Validitas kuesioner diuji 
dengan teknik korelasi Pearson Product Moment untuk mengetahui nilai korelasi antara skor masing-masing variabel dengan skor totalnya. Sedangkan reliabilitas kuesioner diuji dengan menggunakan Croncbach Alpha. Cronbach's alpha digunakan untuk melihat perbandingan antara skala setiap item yang satu dengan yang lainnya secara simultan (Jones, 2010 dan Swarjana, 2016).

Pengolahan data pada penelitian ini dilakukan menggunakan program SPSS (Statistical Product and Service Solution) Statistik 24. Cara analisis data sebagai berikut dimulai dengan menentukan hipotesis :

a. Ha 1 : ada perbedaan yang signifikan terkait pengetahuan $\mathrm{KB}$ oral dan suntik tenaga kesehatan sebelum dan setelah IPE Focus Group Discussion

b. Ha 2 : ada perbedaan yang signifikan terkait persepsi IPE tenaga kesehatan sebelum dan setelah IPE Focus Group Discussion.

c. Ho 1 : tidak ada perbedaan yang signifikan terkait pengetahuan KB oral dan suntik tenaga kesehatan sebelum dan setelah IPE Focus Group Discussion.

d. Ho 2 : tidak ada perbedaan yang signifikan persepsi IPE tenaga kesehatan sebelum dan setelah IPE Focus Group Discussion.

H0 Diterima $=$ Signifikansi $>0,05=$ tidak ada perbedaan yang signifikan persepsi IPE dan terkait pengetahuan KB oral dan suntik tenaga kesehatan sebelum dan setelah IPE Focus Group Discussion, sedangkan H0 Ditolak = Signifikansi $<0,05=$ ada perbedaan yang signifikan persepsi IPE dan terkait pengetahuan $\mathrm{KB}$ oral dan suntik tenaga kesehatan sebelum dan setelah IPE Focus Group Discussion.

Cara mengukur penilaian pengaruh pemberian IPE dalam Focus Group Discussion terhadap pengetahuan tentang $\mathrm{KB}$ oral dan suntik pada tenaga kesehatan dilakukan melalui pendekatan kuantitatif melaui kuesioner dengan skala guttman. Skala Guttman merupakan skala pengukuran yang dapat memberikan jawaban yang tegas pada suatu permasalahan yang ditanyakan (Sugiyono, 2016). Kuesioner dibuat dengan pertanyaan benar-salah, jika jawaban tepat diberi skor 1 dan jika tidak tepat diberi skor 0.

Cara mengukur penilaian persepsi tenaga kesehatan terhadap IPE dalam Focus Group Discussion dilakukan melalui pendekatan kuantitatif menggunakan kuesioner dengan skala likert dimana variabel akan diukur kemudian dijabarkan menjadi indikator variabel (Sugiyono, 2016). Kuesioner tingkat pengetahuan terdiri dari 25 pertanyaan, jika jawabannya SS (Sangat Setuju) diberi skor 6, S (Setuju) diberi skor 5, AS (Agak Setuju) diberi skor 4, ATS (Agak Tidak Setuju) diberi skor 3, TS (Tidak Setuju) diberi skor 2, STS (Sangat Tidak Setuju) diberi skor 1 . 
Penilaian persepsi tenaga kesehatan terhadap IPE dalam Focus Group Discussion dan Pengaruh pemberian IPE dalam Focus Group Discussion terhadap pengetahuan tentang KB oral dan suntik pada tenaga kesehatan dilakukan dengan menggunakan Willcoxon rank test. Willcoxon rank test merupakan uji nonparametrik yang digunakan untuk uji beda pada 2 kelompok sampel yang berpasangan, dengan skala ordinal. Uji Willcoxon rank test digunakan sebagai uji alternatif dari uji $\mathrm{T}$ berpasangan (Paired t-test) yang tidak memenuhi syarat selisih data berpasangan harus berdistribusi normal (Jones, 2010, Swarjana, 2016, dan Sugiyono, 2016). Group yang dilihat adalah tenaga kesehatan aktif, kemudian yang diukur adalah komponen persepsi terhadap IPE dan tingkat pengetahuan tenaga kesehatan tentang KB oral dan suntik. Peneliti pada penelitian ini hanya akan melihat mean antar kelompok dan signifikansi antar komponen dalam analisis ini.

\section{Hasil dan Pembahasan}

\subsection{Hasil uji validitas dan reliabilitas kuesioner}

Sebelum digunakan untuk pengambilan data, kuesioner mengenai pengetahuan KB oral dan suntik dan kuesioner terkait persepsi terhadap IPE diujicobakan terlebih dahulu pada 51 orang responden dengan kriteria inklusi yang sama terhadap responden yang akan diteliti. Validitas kuesioner diuji dengan teknik korelasi Pearson Product Moment. Nilai output tersebut kemudian dibandingkan dengan nilai $\mathrm{r}$ tabel $(\mathrm{n}=51)$ pada signifikansi 0,05 yaitu 0,2706. Berdasarkan hasil output korelasi Pearson Product Moment dengan menggunakan SPSS 24 diketahui bahwa semua nilai $r$ hitung > r tabel artinya 25 butir pertanyaan yang diuji dinyatakan valid, dan layak untuk dijadikan pertanyaan pada kuesioner tentang pengetahuan tenaga kesehatan tentang KB oral dan suntik.

Data validitas kuesioner persepsi tenaga kesehatan terhadap IPE yang dibuat dengan mengadaptasi kuesioner dari PINCOM-Q, IEPS, RIPLS juga digambarkan oleh output korelasi Pearson Product Moment dengan nilai $r$ tabel $(n=51)$ pada signifikansi 0,05 yaitu 0,2706. Berdasarkan hasil output korelasi Pearson Product Moment dengan menggunakan SPSS 24 diketahui bahwa semua nilai $r$ hitung $>r$ tabel artinya 18 butir pertanyaan yang di uji dinyatakan valid, dan layak untuk dijadikan pertanyaan pada kuesioner tentang persepsi tenaga kesehatan terhadap IPE.

Kuesioner selanjutnya diuji kembali dengan uji reabilitas. Reliabilitas kuesioner diuji dengan menggunakan metode Croncbach Alpha. Hasil uji reliabilitas dengan nilai Croncbach Alpha adalah 0,894 , selanjutnya nilai ini dibandingkan dengan nilai $r$ tabel $(n=51)$ pada signifikansi 0,05 yaitu 0,2706. Berdasarkan hasil output diketahui bahwa nilai $r$ hitung > r tabel artinya kuesioner tersebut reliable dengan reliabilitas sangat tinggi. Hal ini sesuai 
dengan kategori indeks reliabilitas menurut Suharsimi (1998) yaitu sangat tinggi (0,8-1), tinggi $(0,6-0,8)$, cukup $(0,4-0,6)$, rendah $(0,2-0,4)$, sangat rendah $(0-0,2)$.

Data reabilitas kuesioner persepsi tenaga kesehatan terhadap IPE yang dibuat dengan mengadaptasi kuesioner dari PINCOM-Q, IEPS, RIPLS juga di uji dengan nilai Croncbach Alpha adalah 0,945, kemudian nilai ini dibandingkan dengan nilai $r$ tabel $(n=51)$ pada signifikansi 0,05 yaitu 0,2706. Berdasarkan hasil output diketahui bahwa nilai $r$ hitung $>r$ tabel artinya kuesioner tersebut reliable dengan reliabilitas sangat tinggi.

Tabel 1. Data Karakteristik responden tenaga kesehatan UPT Puskesmas Caringin, UPT Puskesmas Talaga Bodas, UPT Puskesmas Padasuka, UPT Puskesmas Margahayu Raya, UPT Puskesmas Ujung Berung, dan UPT Puskesmas Garuda.

\begin{tabular}{|c|c|c|}
\hline Variabel & Frekuensi $(\mathrm{N}=161)$ & Presentase (\%) \\
\hline \multicolumn{3}{|l|}{ Puskesmas } \\
\hline UPT Caringin & 30 & 18,63 \\
\hline UPT Garuda & 32 & 19,88 \\
\hline UPT Margahayu Raya & 23 & 14,29 \\
\hline UPT Padasuka & 34 & 21,12 \\
\hline UPT Talaga Bodas & 21 & 13,04 \\
\hline UPT Ujung Berung & 21 & 13,04 \\
\hline \multicolumn{3}{|l|}{ Jenis Kelamin } \\
\hline Laki-laki & 18 & 11,18 \\
\hline Perempuan & 143 & 88,82 \\
\hline \multicolumn{3}{|l|}{ Usia } \\
\hline $21-25$ tahun & 19 & 11,80 \\
\hline $26-30$ tahun & 68 & 42,24 \\
\hline $31-35$ tahun & 53 & 32,92 \\
\hline $36-40$ tahun & 16 & 9,94 \\
\hline Di atas 40 tahun & 5 & 3,11 \\
\hline \multicolumn{3}{|l|}{ Profesi } \\
\hline Apoteker & 6 & 3,73 \\
\hline Dokter & 27 & 16,77 \\
\hline Perawat & 42 & 26,09 \\
\hline Bidan & 48 & 29,81 \\
\hline SKM & 22 & 13,66 \\
\hline Asisten Apoteker & 9 & 5,59 \\
\hline PLKB & 7 & 4,35 \\
\hline \multicolumn{3}{|l|}{ Tingkat Pendidikan } \\
\hline SMK & 4 & 2,48 \\
\hline D3 & 72 & 44,72 \\
\hline S1 & 44 & 27,33 \\
\hline Profesi & 40 & 24,84 \\
\hline $\mathrm{S} 2 /$ Spesialis & 1 & 0,62 \\
\hline \multicolumn{3}{|l|}{ Masa Kerja } \\
\hline$<10$ tahun & 107 & 66,46 \\
\hline$>10$ tahun & 54 & 33,54 \\
\hline
\end{tabular}

\subsection{Gambaran umum karakteristik responden}

Karakteristik tenaga kesehatan yang menjadi responden dapat dilihat pada Tabel 1. Responden di dominasi oleh perempuan, mengingat bahwa jumlah apoteker dan perawat 
perempuan lebih banyak dibandingkan laki-laki. Usia responden didominasi oleh usia 26-35 tahun. Pada kelompok usia ini, seseorang masih masuk ke dalam usia produktif sehingga persentasenya lebih banyak. Masa kerja responden didominasi oleh $<10$ tahun. Masa kerja akan berhubungan dengan pendalaman pengetahuan terhadap bidang yang ditekuni.

\subsection{Hasil Uji Normalitas Data Kuesioner}

Uji Normalitas diperlukan untuk membuktikan bahwa data selisihnya tidak terdistribusi normal, sehingga tidak dapat dilakukan uji parametrik dengan uji $\mathrm{T}$ berpasangan dan melakukan uji Willcoxon rank test digunakan sebagai uji alternatif (Jones, 2010, Swarjana, 2016, dan Sugiyono, 2016). Data hasil uji normalitas kuesioner pengetahuan pada 6 puskesmas di Kota Bandung dengan metode Kolmogorov-Smirnov karena jumlah responden $>$ 50. Hasil uji normalitas pada data tingkat pengetahuan tenaga kesehatan di Kota Bandung menunjukkan p-value pada Kolmogorov-Smirnov adalah $0,000<\alpha 0,05$ dimana hal ini menunjukan data tidak terdistribusi normal. Data hasil uji normalitas kuesioner persepsi tenaga kesehatan terhadap IPE pada 6 puskesmas di Kota Bandung dengan metode Kolmogorov-Smirnov menunjukkan tidak terdistribusi normal yang ditunjukkan dengan pvalue $0,000<\alpha 0,05$. Hal ini mengarahkan bahwa uji hipotesis dapat dilakukan dengan uji nonparametrik.

\subsection{Pengaruh IPE Focus Group Discussion terhadap tingkat pengetahuan tenaga kesehatan}

Analisis pengaruh IPE Focus Group Discussion terhadap tingkat pengetahuan tenaga kesehatan di Kota Bandung dilakukan pada 6 puskesmas yang dilakukan dengan melakukan penilaian sebelum (pre test) dan sesudah (post test) dilaksanakan FGD antar profesi untuk mengetahui terkait tingkat pengetahuan tentang $\mathrm{KB}$ oral dan suntik di puskesmas tersebut. Hipotesis penelitian ini adalah ada perbedaan yang signifikan terkait persepsi terhadap IPE oleh tenaga kesehatan sebelum dan setelah IPE Focus Group Discussion. Analisis data dilakukan menggunakan statistik non parametrik yaitu uji Wilcoxon sign rank test untuk membuktikan hipotesis. Hasil analisis deskriptif tingkat pengetahuan tenaga kesehatan tentang KB oral dan suntik pada saat Pretest - Postest dapat dilihat pada Tabel 2.

Tabel 2. Hasil analisis deskriptif tingkat pengetahuan tenaga kesehatan tentang $\mathrm{KB}$ oral dan suntik pada saat Pretest - Postest.

\begin{tabular}{lcccc}
\hline & N & Rata-rata \pm SD & Minimum & Maximum \\
\hline Pre Test Pengetahuan & 161 & $15,5 \pm 2,530$ & 9 & 23 \\
Post Test Pengetahuan & 161 & $19,32 \pm 2,024$ & 14 & 23 \\
\hline
\end{tabular}


Hasil analisis deskriptif pada Tabel 2 dapat dilihat bahwa terdapat perbedaan tentang tingkat pengetahuan tenaga kesehatan antara data pretest dan postest tingkat pengetahuan tenaga kesehatan tentang $\mathrm{KB}$ oral dan suntik. Hasil analisis data pengukuran tingkat pengetahuan tenaga kesehatan tentang $\mathrm{KB}$ oral dan suntik pada pretest diperoleh nilai rata-rata $=15,50$ dengan simpangan baku (standar deviation) $=2,530$. Setelah IPE Focus Group Discussion dilakukan, pengujian kembali (post test) dilakukan dan diperoleh nilai rata-rata $=$ 19,32 dengan simpangan baku (standar deviation) $=2,024$.

Tabel 3. Hasil analisis Wilcoxon Signed Rank Test tingkat pengetahuan tenaga kesehatan tentang KB oral dan suntik pada saat Pretest - Postest. Keterangan: Post Test Pengetahuan < Pre Test Pengetahuan (a), Post Test Pengetahuan > Pre Test Pengetahuan (b) dan Post Test Pengetahuan $=$ Pre Test Pengetahuan.

\begin{tabular}{|c|c|c|c|c|}
\hline & & $\begin{array}{c}\text { Ranks } \\
\text { (N) }\end{array}$ & Mean Rank & Sum of Ranks \\
\hline Post Test & Negative & $5^{\mathrm{a}}$ & 25.40 & 127.00 \\
\hline Pengetahuan - Pre & Ranks & & & \\
\hline Test Pengetahuan & $\begin{array}{l}\text { Positive Ranks } \\
\text { Ties } \\
\text { Total }\end{array}$ & $\begin{array}{c}152^{b} \\
4^{c} \\
161\end{array}$ & 80.76 & 12276.00 \\
\hline
\end{tabular}

Hasil uji hipotesis perbedaan tingkat pengetahuan responden saat pretest-postes dapat dilihat pada table 3. Berdasarkan hasil analisis Wilcoxon Signed Rank Test pada Tabel 3 tentang tingkat pengetahuan tenaga kesehatan pada saat Pretest dan Postest di gambarkan dalam bentuk rank (peringkat). Dalam penelitian ini diperoleh 5 data negatif $(\mathrm{N})$ artinya 5 orang tenaga kesehatan mengalami penurunan tingkat pengetahuan, rata-rata penurunan (mean rank) tersebut adalah sebesar 25,40, sedangkan jumlah rangking negatif (sum of rank) adalah 127,00. Dalam penelitian ini diperoleh 152 data positif $(\mathrm{N})$ artinya 152 orang tenaga kesehatan mengalami peningkatan tingkat pengetahuan, rata-rata peningkatan (mean rank) tersebut adalah sebesar 80,76, sedangkan jumlah rangking positif (sum of rank) adalah 12276.00. Sedangkan ties adalah nilai kelompok kedua (posttest) sama besarnya dengan nilai kelompok pertama (pretest), dalam penelitian ini diperoleh 4 data $(\mathrm{N})$ artinya 4 orang tenaga kesehatan tidak mengalami peningkatan maupun penurunan tingkat pengetahuan. Untuk menentukan pengaruh IPE terhadap pengetahuan responden dilakukan uji hipotesis dengan Wilcoxon Signed Rank Test (Tabel 4).

Tabel 4. Hasil Uji Hipotesis dengan Wilcoxon Signed Rank Test tentang tingkat pengetahuan tenaga kesehatan tentang KB oral dan suntik. Keterangan: Wilcoxon Signed Ranks Test (a) dan Based on negative ranks (b).

\begin{tabular}{lc}
\hline \multicolumn{2}{c}{ Post Test Pengetahuan - Pre Test Pengetahuan } \\
\hline $\mathrm{Z}$ & $-10.676^{\mathrm{b}}$ \\
Asymp. Sig. (2-tailed) & .000 \\
\hline
\end{tabular}


Dasar pengambilan keputusan dalam uji Wilcoxon Signed Rank Test yaitu jika nilai Asymp. Sig. (2-tailed) lebih kecil dari $0,05(<\alpha 0,05)$ maka Ha diterima, begitupula sebaliknya (Jones, 2010). Berdasarkan data Test Statistics diketahui nilai Asymp. Sig. (2tailed) adalah 0,000, karena nilai $0,000<0,05$ maka dapat dikatakan IPE Focus Group Discussion berpengaruh terhadap tingkat pengetahuan responden.

\subsection{Pengaruh IPE Focus Group Discussion terhadap persepsi tenaga kesehatan tentang IPE}

Analisis pengaruh IPE Focus Group Discussion terhadap persepsi tentang IPE tenaga kesehatan di Kota Bandung dilakukan pada 6 puskesmas yang dilakukan dengan melakukan penilaian sebelum (pre test) dan sesudah (post test) dilaksanakan FGD antar profesi untuk mengetahui persepsi tenaga kesehatan tentang IPE (kolaborasi antarprofesi) di puskesmas tersebut. Hipotesis penelitian ini adalah ada perbedaan yang signifikan terkait persepsi terhadap IPE oleh tenaga kesehatan sebelum dan setelah IPE Focus Group Discussion. Analisis data dilakukan menggunakan statistik non parametrik yaitu uji Wilcoxon sign rank test untuk membuktikan hipotesis. Hasil analisis deskriptif persepsi tenaga kesehatan terhadap IPE dapat dilihat pada Tabel 5.

Tabel 5. Hasil analisis deskriptif persepsi tenaga kesehatan tentang IPE di Kota Bandung dilakukan pada 6 puskesmas pada saat Pretest-Postest.

\begin{tabular}{lcccc}
\hline & N & Nilai rata-rata \pm SD & Minimum & Maximum \\
\hline Pre Test IPE & 161 & $92,53 \pm 6,72$ & 72 & 108 \\
Post Test IPE & 161 & $97,73 \pm 7,72$ & 81 & 108 \\
\hline
\end{tabular}

Hasil analisis deskriptif pada Tabel 5 dapat dilihat bahwa terdapat perbedaan tentang persepsi tenaga kesehatan tentang IPE antara data pretest dan postest tingkat pengetahuan tenaga kesehatan tentang KB oral dan suntik. Hasil analisis data pengukuran persepsi tenaga kesehatan tentang IPE pada pretest diperoleh mean $(M)=92,53$ dengan simpangan baku $($ standar deviation $)=6,72$. Setelah IPE Focus Group Discussion dilakukan, pengujian kembali (post test) dilakukan dan diperoleh mean $(\mathrm{M})=97,73$ dengan simpangan baku (standar deviation $)=7,72$. Hasil analisis Wilcoxon Signed Rank Test persepsi tenaga kesehatan tentang IPE pada saat Pretest dan Postest dapat dilihat pada Tabel 7.

Berdasarkan hasil analisis Wilcoxon Signed Rank Test pada Tabel 6 diperoleh 22 data negatif $(\mathrm{N})$ artinya 22 orang tenaga kesehatan mengalami penurunan persepsi tentang IPE, rata-rata penurunan (mean rank) tersebut adalah sebesar 51,39, sedangkan jumlah rangking negatif (sum of rank) adalah 1130,50. Dalam penelitian ini diperoleh 114 data positif $(\mathrm{N})$ artinya 114 orang tenaga kesehatan mengalami peningkatan persepsi tentang IPE, rata-rata peningkatan (mean rank) tersebut adalah sebesar 71,80, sedangkan jumlah rangking positif 
(sum of rank) adalah 8185,50. Sedangkan ties adalah nilai kelompok kedua (posttest) sama besarnya dengan nilai kelompok pertama (pretest), dalam penelitian ini diperoleh 25 data $(\mathrm{N})$ artinya 25 orang tenaga kesehatan tidak mengalami peningkatan maupun penurunan persepsi tentang IPE.

Tabel 6. Hasil analisis Wilcoxon Signed Rank Test persepsi tenaga kesehatan tentang IPE pada saat Pretest dan Postest. Keterangan: Post Test IPE < Pre Test IPE (a), Post Test IPE $>$ Pre Test IPE (b) dan Post Test IPE = Pre Test IPE (c).

\begin{tabular}{llccc}
\hline & & Ranks (N) & Mean Rank & Sum of Ranks \\
\hline Post Test IPE - Pre Test & Negative Ranks & $22^{\mathrm{a}}$ & 51.39 & 1130.50 \\
IPE & Positive Ranks & $114^{\mathrm{b}}$ & 71.80 & 8185.50 \\
& Ties & $25^{\mathrm{c}}$ & & \\
& Total & 161 & & \\
\hline
\end{tabular}

Data pada tabel 7 menunjukkan hasil uji hipotesis dengan menggunakan output SPSS 24 yaitu data Test Statistics. Berdasarkan data Test Statistics diketahui nilai Asymp. Sig. (2tailed) adalah 0,000, karena nilai 0,000 $<0,05$ sehingga dapat dikatakan ada perbedaan persepsi responden sebelum dan setelah IPE. Berdasarkan hasil penelitian dapat diketahui bahwa pelaksanaan IPE Focus Group Discussion berpengaruh terhadap tingkat pengetahuan dan persepsi tenaga kesehatan. Hal ini disebabkan oleh faktor anteseden (pertimbangan social, lingkungan fisik, faktor organisasional) dan proses (perilaku, interpersonal, intelektual) yang dapat mendukung dan meningkatkan fungsi kerjasama tim yang lebih efektif sehingga menyebabkan perubahan hasil dan signifikansinya dimana faktor-faktor inilah yang dapat meningkatkan ataupun menghambat proses kerjasama dalam tim (Weaver, 2008). Bahrir (2015) menyatakan bahwa bahwa faktor-faktor yang sangat berhubungan dengan kolaborasi adalah komunikasi, dimana semakin baik komunikasi maka semakin baik praktik kolaborasi. Oleh karena itu, kemampuan dan keterampilan dalam melakukan komunikasi serta persepsi tentang kolaborasi menentukan praktik kolaborasi.

Tabel 7. Hasil Uji Hipotesis dengan Wilcoxon Signed Rank Test persepsi tenaga kesehatan tentang IPE. Keterangan: Wilcoxon Signed Ranks Test (a) dan Based on negative ranks (b).

\begin{tabular}{|c|c|}
\hline \multicolumn{2}{|c|}{ 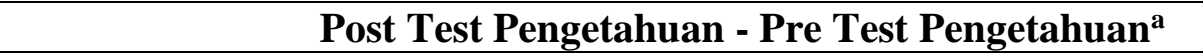 } \\
\hline $\mathrm{Z}$ & $-7.669^{b}$ \\
\hline Asymp. Sig. (2-tailed) & .000 \\
\hline
\end{tabular}

IPE membantu siswa dalam meningkatkan pemahaman mereka tentang pekerjaan interprofesional, meskipun sistem perawatan kesehatan dan sistem pendidikan berbeda dengan negara barat, namun pendidikan interpersonal di jepang dan negara lain akan serupa dengan yang terjadi di negara barat. Penelitian Fallatah, dkk (2015) juga menyatakan bahwa 
penerapan IPE dalam pendidikan mereka akan memperbaiki kepuasan pasien dan perawatan terhadap pasien serta peningkatan persepsi siswa terhadap efektivitas IPE yang berefek pada peningkatkan kemampuan kerja sama tim dan keterampilan komunikasi.

\section{Kesimpulan}

Ada perbedaan yang signifikan terkait pengetahuan $\mathrm{KB}$ oral dan suntik serta persepsi tenaga kesehatan tentang IPE sebelum dan setelah IPE Focus Group Discussion.

\section{Ucapan Terima Kasih}

Penulis ucapkan terimakasih kepada BKKBN Kota Bandung, Prodi Farmasi Universitas Harapan Bangsa, Prodi Farmasi Universitas Garut, Sekolah Farmasi ITB, dan seluruh tenaga medis di Puskesmas yang menjadi objek penelitian yang membantu di dalam pengerjaan hingga mendapatkan hasil penelitian.

\section{Daftar Pustaka}

Allen, R. H., \& Cwiak, C. A. (2014). Contraception for the Medically Challenging Patient. https://doi.org/10.1007/978-1-4939-1233-9

Bahrir, I. N. (2015). Hubungan Komunikasi Perawat Dokter dengan Praktek Kolaborasi di Instalasi Rawat Inap RSUD H.A. Sulthan DG. Radja Bulukumba. Universitas Hassanudin.

Barr, H., \& Low, H. (2013). CAIPE: Introducing Interprofessional Education. Educating Health Professionals: Becoming a University Teacher. https://doi.org/10.1007/978-946209-353-9_16

BKKBN. (2017). Sinergi Dukungan Kegiatan dan Anggaran BKKBN dalam Peningkatan Pelayanan KB di Fasilitas Kesehatan. Jakarta.

Cappiello, J., Levi, A., \& Nothnagle, M. (2016). Core competencies in sexual and reproductive health for the interprofessional primary care team. Contraception, 93(5), 438-445. https://doi.org/10.1016/j.contraception.2015.12.013

Fallatah, H. I., Jabbad, R., \& Fallatah, H. K. (2015). Interprofessional Education as a Need: The Perception of Medical, Nursing Students and Graduates of Medical College at King Abdulaziz University. Creative Education, 6(February), 248-254. Retrieved from http://dx.doi.org/10.4236/ce.2015.62023

Health, Y. M., Street, H., Laurin-lamothe, A., Mental, Y., Nadeau, L., Health, Y. M., ... Health, M. (2012). Measuring the quality of interprofessional collaboration in child mental health collaborative care, 12 (February).

Jones, D. S. (2010). Statistik Farmasi. (N. Aini, H. U. Ramdaniati, \& H. Rivai, Eds.). Jakarta: Penerbit Buku Kedokteran EGC.

Kemenkes. (2014a). Pedoman Manajemen: Pelayanan Keluarga Berencana. Direktorat Jenderal Bina Kesehatan Ibu Kemenkes.

Kemenkes. (2014b). Peraturan Menteri Kesehatan Republik Indonesia Nomor 75 Tahun 2014 tentang Kesehatan $\quad$ Masyarakat. 2014. https://doi.org/10.1017/CBO9781107415324.004

Kemenkes. (2015). Rencana Strategis Kementerian Kesehatan 2015 - 2019. https://doi.org/351.077 Indr

Levi, A., Burdette, L., Hill-Besinque, K., \& Murphy, P. A. (2013). The interprofessional sexual and reproductive health care team. Contraception, 88(2), 213-214. https://doi.org/10.1016/j.contraception.2013.05.011

Maeno, T., Takayashiki, A., Anme, T., Tohno, E., Maeno, T., \& Hara, A. (2013). Japanese students' perception of their learning from an interprofessional education program: a qualitative study. International Journal of Medical Education, 4, 9-17. https://doi.org/10.5116/ijme.50e5.e29a

McFadyen, a K., Maclaren, W. M., \& Webster, V. S. (2007). The Interdisciplinary Education 
Perception Scale (IEPS): an alternative remodelled sub-scale structure and its reliability. Journal of Interprofessional Care, 21(4), 433-43. https://doi.org/10.1080/13561820701352531

Parsell, G., \& Bligh, J. (1999). The development of a questionnaire to assess the readiness of health care students for interprofessional learning ( RIPLS ), 95-100.

Senanayake, P. and M. P. (2008). Atlas of Contraception Second edition (Second edi). UK: Replika Press Pvt Ltd.

Sugiyono. (2016). Metode Penelitian Kuantitatif, kualitatif dan $R \& D$. Bandung: Alfabeta. https://doi.org/10.1017/CBO9781107415324.004

Swarjana, I. K. (2016). Statistik Kesehatan. Yogyakarta: CV Andi Offset.

Ulung, D. K. (2014). Persepsi Mahasiswa Fakultas Kedokteran dan Ilmu Kesehatan UIN Syarif Hidayatullah Jakarta terhadap Interprofessional Education. Universitas Islam Negeri Syarif Hidayatullah Jakarta.

Weaver, T. E. (2008). Enhancing multiple disciplinary teamwork. Nursing Outlook, 56(3). https://doi.org/10.1016/j.outlook.2008.03.013

\section{(c) (1) (2)

